\title{
Characterization of Polychlorinated Dibenzo-p-dioxins and Dibenzofurans in the Stack Flue Gas of a Municipal Solid Waste Incinerator, in the Ambient Air, and in the Banyan Leaf
}

\author{
Mao-Sung Wang ${ }^{1 *}$, Lin-Chi Wang ${ }^{1}$, Guo-Ping Chang-Chien ${ }^{1}$, and Long-Full Lin ${ }^{2}$ \\ ${ }^{I}$ Department of Chemical and Materials Engineering, Cheng Shiu University. \\ 840, Chengching Rd., Kaohsiung 833, Taiwan, ROC \\ ${ }^{2}$ Department of Environmental Engineering, National Cheng Kung University. \\ 1, University Rd., Tainan 70101, Taiwan, ROC
}

\begin{abstract}
The municipal solid waste incinerator (MSWI-JW) situated in a highly industrialized area in the Renwu Township, Kaohsiung County of southern Taiwan was chosen to assess the impact of polychlorinated dibenzo-p-dioxins and dibenzofurans (PCDD/Fs) emission on ambient air and vegetation. A total of seven ambient air and banyan leaf sites located in the vicinity of the MSWI-JW were sampled and analyzed for PCDD/Fs. The congener profiles of 2,3,7,8 chlorine-substituted PCDD/Fs were selected as the fingerprint, and the PCDD/F congener profile in the stack flue gas of MSWI, and those of the ambient air and the banyan leaf were analyzed by principle component analysis to clarify the pollution sources of the affected receptors. The mean PCDD/F concentration in the stack flue gas was $0.0593 \mathrm{ng}$ I-TEQ Nm${ }^{-3}$ $(\mathrm{n}=2)$. The PCDD/F concentration in ambient air ranged between 0.037 and 0.111 and averaged $0.080 \mathrm{pg}$ I-TEQ Nm${ }^{-3}$ (RSD: $26.9 \%$; $=14$ ). The PCDD/F composition in banyan leaves ranged between 0.804 and 7.48 and averaged $2.83 \mathrm{ng}$ I-TEQ per kilogram of dry leaves (RSD: 61.9\%; $\mathrm{n}=14$ ). Whether ambient air or banyan leaf, the relationship between PCDD/F concentration isopleths does not match the geographic position of MSWI-JW and wind rose. The results of PCA analysis coincided with the relationship between PCDD/F concentration isopleths and the geographic position of MSWI-JW and wind rose. These all reveal that the PCDD/F emissions from MSWI-JW have no significant influence on the ambient air and banyan leaf receptors; that is, the MSWI-JW is not responsible for the main contribution of PCDD/Fs in the ambient air and banyan leaf. Other potential emission sources of PCDD/Fs could be of greater importance.
\end{abstract}

\footnotetext{
${ }^{*}$ Corresponding author: Tel.: +886-7-7310606 ext.3921; Fax: +886-7-7312204;

E-mail address: maosung@csu.edu.tw
} 
Keywords: PCDD/Fs; municipal solid waste incinerator; principle component analysis; congener profile; banyan leaf

\section{INTRODUCTION}

Incineration was adopted in Taiwan as the main technology for treating municipal solid wastes because of the country's high population density. In contrast with other countries, Taiwan's municipal solid waste incinerators (MSWIs) are larger and newer; only six of the existing MSWIs started operation before 1999 (Lee et al., 2004B). Consequently, PCDD/F control technologies adopted by these MSWIs are relatively new and are expected to perform well. The PCDD/F emission limit of large scale MSWIs is regulated at $0.1 \mathrm{ng}$ I-TEQ $\mathrm{Nm}^{-3}$ by Taiwan EPA, which is the most stringent in the world, and results in emissions classified as "insignificant" for all plant sizes (Eduljee and Gair, 1997). Although the PCDD/F concentration in the stack flue gases of MSWIs is low, the influence of PCDD/F emission from MSWIs on ambient air is still a public concern. The stack flue gas emitted from this emission source contains mixtures of PCDD/F congeners. These mixtures can be translated into profiles which represent the distribution of individual PCDD/Fs (Buekens et al., 2000; Domingo et al., 2001; Schummacher et al., 2002; Lee et al., 2003; Wang et al., 2003A; Wang et al., 2003B; Kim et al., 2005). These profiles may serve as a signature, or fingerprint, of the types of PCDD/Fs associated with particular incinerators and air pollution control devices. Fingerprinting PCDD/Fs has resulted in interesting applications for source identification.

Considering the potential variability and concentrations of PCDD/F emission in ambient air, average atmospheric levels are not necessarily the most adequate monitor for these compounds. To address this, soil and vegetation matrices located in the vicinity of the emission source have been used in the environmental monitoring of MSWIs (Schummacher et al., 1997; Schummacher et al., 1998; Schummacher et al., 2000; Domingo et al., 2001; Nadal et al., 2002). Evaluation of PCDD/F concentrations in vegetation can produce information on short-term exposure to these compounds (Schummacher et al., 1997). In general, PCDD/F uptake from soil via the roots into above-ground parts of plants would be insignificant, since the primary mechanism by which PCDD/Fs enter the plant is via atmospheric deposition (USEPA, 1995).

Our research group evaluated the transfer of PCDD/Fs into banyan leaves and found that the primary pathway for PCDD/Fs entering the banyan leaves was by particle phase absorption (86.4\%). Another pathway was by gas phase absorption. Using pseudo first-order kinetics, the decomposition coefficient (including the photolysis and the biodegradation coefficient) of total PCDD/Fs was $0.0499 \mathrm{~d}^{-1}$. The mean half-life of seventeen PCDD/F congeners was 276 hours (Hung, 2003). 
We also investigated relationships among seventeen 2,3,7,8-substituted PCDD/Fs found between the monitored emission source and banyan leaf receptors, as well as in the ambient air. The MSWI-JW, situated in a highly industrialized area in southern Taiwan, was chosen to characterize PCDD/F emission in the stack flue gas, ambient air, and banyan leaf. The relationships between the emission source, ambient air, and banyan leaf receptor were analyzed by applying principal component analysis (PCA) (Fiedler et al.,1996; Schummacher et al., 1997; Schummacher et al., 1998; Buekens et al., 2000; Schummacher et al., 2002; Domingo et al., 2002; Kim et al., 2005). Relationships between meteorological conditions (wind rose) and the PCDD/F concentration in the selected geographical location were also examined.

\section{MATERIALS AND METHODS}

\section{SAMPLING FOR STACK FLUE GAS}

A basic description of the MSWI-JW is provided in Table 1. Following the definitions of the US EPA (USEPA, 1998), the design type of the MSWI-JW is a modular excess-air system. It consists of three sets of incinerators and heat recovery systems, selective non-catalytic reduction, semi-dry scrubber, activated carbon injection, fabric filter and stack. The MSWI-JW operates continuously. The stack flue gas from the MSWI-JW was sampled twice, once in June 2003 and again September 2003. These two PCDD/F samples were collected according to US EPA modified Method 23, and analysis was performed by an accredited laboratory certified by the Taiwan EPA. The sampling train adopted in this study is comparable to that specified by the US EPA modified Method 5. Prior to sampling, XAD-2 resin was spiked with PCDD/F surrogate standards prelabeled with isotopes. Each sampling period lasted for about $3 \mathrm{~h}$. To ensure that the collected samples were contamination free, one trip blank and one field blank were also used during the field sampling.

\section{SAMPLING FROM AMBIENT AIR AND BANYAN LEAF}

Ambient air and banyan leaves in the vicinity of MSWI-JW were sampled twice, first in May 2003, then in September 2003. In each sampling period, seven ambient air and seven banyan leaf samples were collected. Sampling site locations are mapped in Fig. 1. Each ambient air sample was collected using a PS-1 sampler (Graseby Anderson, GA, USA) according to the revised U.S. EPA Compendium Method TO-9A. The sampling flow rate was $0.225 \mathrm{~m}^{3} \mathrm{~min}^{-1}$. Each sample was collected continuously on three consecutive days yielding a sampling volume of $972 \mathrm{~m}^{3}$. The PS-1 sampler was equipped with a quartzfiber filter for sampling particle-phase PCDD/Fs, which was followed by a glass cartridge containing 
PUF for sampling gas-phase PCDD/Fs. A known amount of surrogate standard was spiked to the PUF in the laboratory before the field sampling was conducted. Banyan leaf samples were obtained by cutting at least $10 \mathrm{~cm}$ above soil level. Leaves that were too fresh and too old were avoided. Samples were immediately packed in aluminum foil, cleaned later with tap water to remove dust on the surface of leaf, then dried at room temperature for one week. Samples were prepared by grinding them with a cutting mill to a fine powder and then homogenized. Approximately $10 \mathrm{~g}$ were used for analytical purposes. The $\mathrm{PCDD} / \mathrm{F}$ composition is from the interior constitution and is expressed on the basis of kilogram dry weight of the leaves.

Table 1. Basic Description of the Municipal Solid Waste Incinerator JW

\begin{tabular}{cc}
\hline Incinerator & JW \\
Design type & Modular incinerator with excess-air \\
Operation type & Continuous \\
Feeding waste & Municipal solid waste \\
Capacity & 1350 tons day $^{-1}$ \\
Emission temperature of stack flue gas & $135^{\circ} \mathrm{C}$ \\
Stack height & $120 \mathrm{~m}$ \\
Stack diameter & $1.8 \mathrm{~m}$ \\
Emission velocity of stack flue gas & $18 \mathrm{~m} \mathrm{~s}^{-1}$ \\
& ${\text { Selective non-catalytic reduction }\left(900^{\circ} \mathrm{C}\right)}$ \\
Air pollution control devices in sequence & $\downarrow$ \\
(Operation temperature) & Semi-dry scrubber $\left(230 \sim 245^{\circ} \mathrm{C}\right)$ \\
& ${\text { Activated carbon injection }\left(165^{\circ} \mathrm{C}\right)}$ \\
Regulatory emission standard of PCDD/Fs & Fabric filter $\left(165^{\circ} \mathrm{C}\right)$ \\
\end{tabular}

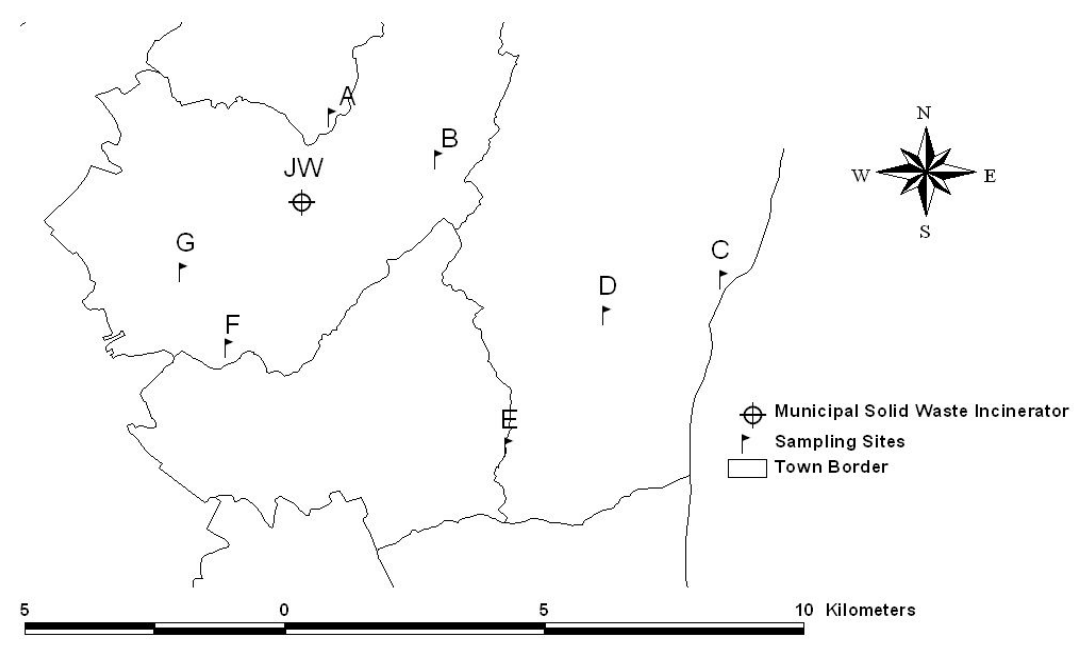

Figure 1. Sampling sites of ambient air in the vicinity of municipal solid waste incinerator JW 


\section{PCDD/F ANALYSIS}

PCDD/F analyses of stack flue gas, ambient air, and banyan leaves samples followed the U.S. EPA modified Method 23, the U.S. EPA Compendium Method TO-9A, and the revised U.S. EPA Method 1613, respectively. All chemical analyses were conducted by the Super Micro Mass Research and Technology Center in Cheng-Shiu University, certified by the Taiwan EPA for analyzing PCDD/Fs. Each collected sample was spiked with a known amount of the internal standard solution to the extraction thimble prior to PCDD/F analysis. After being extracted for $24 \mathrm{~h}$, the extract was concentrated, treated with concentrated sulphuric acid, and followed by a series of sample cleanup and fractionation procedures. The elute was concentrated to approximately $1 \mathrm{~mL}$ and transferred to a vial. The concentrate was further concentrated to near dryness, using a stream of nitrogen. Immediately prior to analysis, the standard solution was added to the sample to ensure the recovery during the analysis process. Two highresolution gas chromatographs/high-resolution mass spectrometers (HRGC/HGMS) were used for $\mathrm{PCDD} / \mathrm{F}$ analyses (one for stack flue gas samples, and the other for both ambient air and banyan leaf samples). The HRGC (Hewlett Packard 6970 Series, CA, USA) was equipped with a splitless injection and a DB-5 fused silica capillary column (60 m length, $0.25 \mathrm{~mm}$ ID, and $0.25 \mu \mathrm{m}$ film thickness) (J\&W Scientific, CA, USA). The oven temperature program was set as follows: begin at $150^{\circ} \mathrm{C}$ (held for $1 \mathrm{~min}$ ), then increased at $30^{\circ} \mathrm{C} \mathrm{min}^{-1}$ to $220^{\circ} \mathrm{C}$ (held for $12 \mathrm{~min}$ ), then increased at $1.5^{\circ} \mathrm{C} \min ^{-1}$ to $240^{\circ} \mathrm{C}$ (held for $5 \mathrm{~min}$ ), and finally increased at $1.5^{\circ} \mathrm{C} \mathrm{m^{-1 }}$ intervals to $310^{\circ} \mathrm{C}$ (held for $20 \mathrm{~min}$ ). Helium was used as the carrier gas. The HRMS (Micromass Autospec Ultima, Manchester, UK) was equipped with a positive electron impact (EI+) source. The analyzer mode of the selected ion monitoring (SIM) with a resolving power at 10,000 was used. The electron energy and source temperature were specified at $35 \mathrm{eV}$ and $250^{\circ} \mathrm{C}$, respectively.

\section{PRINCIPLE COMPONENT ANALYSIS}

Principle component analysis (PCA) was used to interpret the relationship between the emission source and ambient air receptor, and between the emission source and banyan leaf receptor. The data were divided into cases (in this study, PCDD/F emission sources, ambient air receptors, and banyan leaf receptors) and variables (the fractions of seventeen 2,3,7,8 chlorine-substituted congeners). The variables were used to characterize the cases. In the graphic associated with the cases (score plot), the cases with similar patterns will be located close to each other, while those which have divergent patterns will be located further apart; the cases were classified according to the position of their corresponding coordinates with respect to the factor axis (Jambu, 1991; Lee et al., 2004a; Lee et al., 2004b). PCA 
allows a multi-dimensional dataset to be projected onto two or three dimensions in a way that much of the information of the original data is retained.

\section{RESULTS AND DISCUSSIONS}

\section{PCDD/FS IN THE STACK FLUE GAS}

The mean PCDD/F concentration in the stack flue gas was found to be $0.0593 \mathrm{ng} \mathrm{I}^{-T E Q ~ N m}{ }^{-3}(\mathrm{n}=2)$. The PCDD/F concentration is lower than the PCDD/F emission standard $\left(0.1 \mathrm{ng} \mathrm{I-TEQ} \mathrm{Nm}{ }^{-3}\right)$ of large scale MSWIs regulated by the Taiwan EPA. The congener profiles of the seventeen 2,3,7,8 chlorinesubstituted PCDD/Fs were selected as the fingerprints of the MSWI-JW. Fig. 2 shows the congener profile of the "dirty" seventeen PCDD/Fs (mean \pm SD) detected from the stack flue gases. Each selected congener was normalized by reference to the total weight of all 2,3,7,8-congeners. The variable " $n$ " represents the number of total stack flue gas samples. In the stack flue gases of MSWI-JW, OCDD is the major congener, followed by: 1,2,3,4,6,7,8-HpCDD; 1,2,3,4,6,7,8-HpCDF; and OCDF. The congener profile of MSWI-JW is similar to those presented in other research (US EPA, 1998; Lee et al., 2003; Lee et al., 2004a; Lee et al., 2004b).

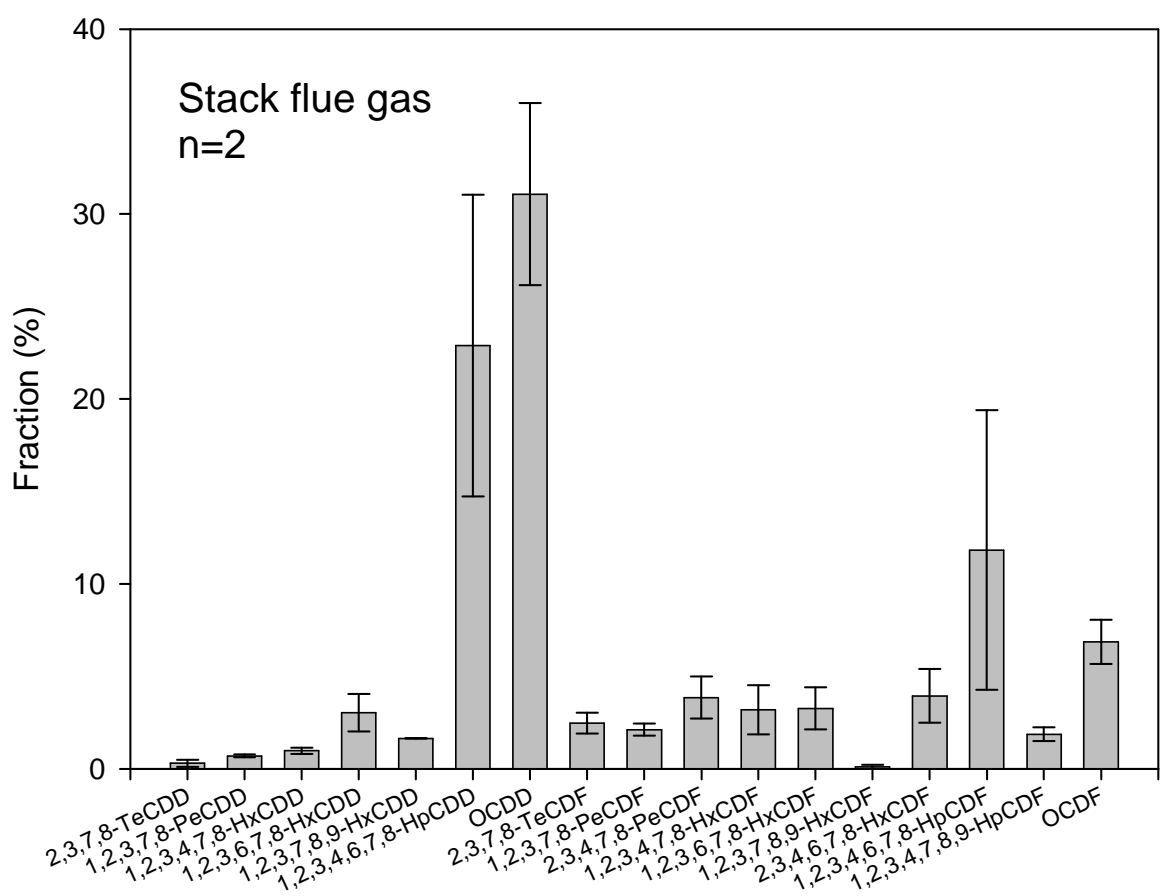

Figure 2. Congener profile of seventeen 2,3,7,8 chlorine-substituted PCDD/Fs in the stack flue gases of JW. 


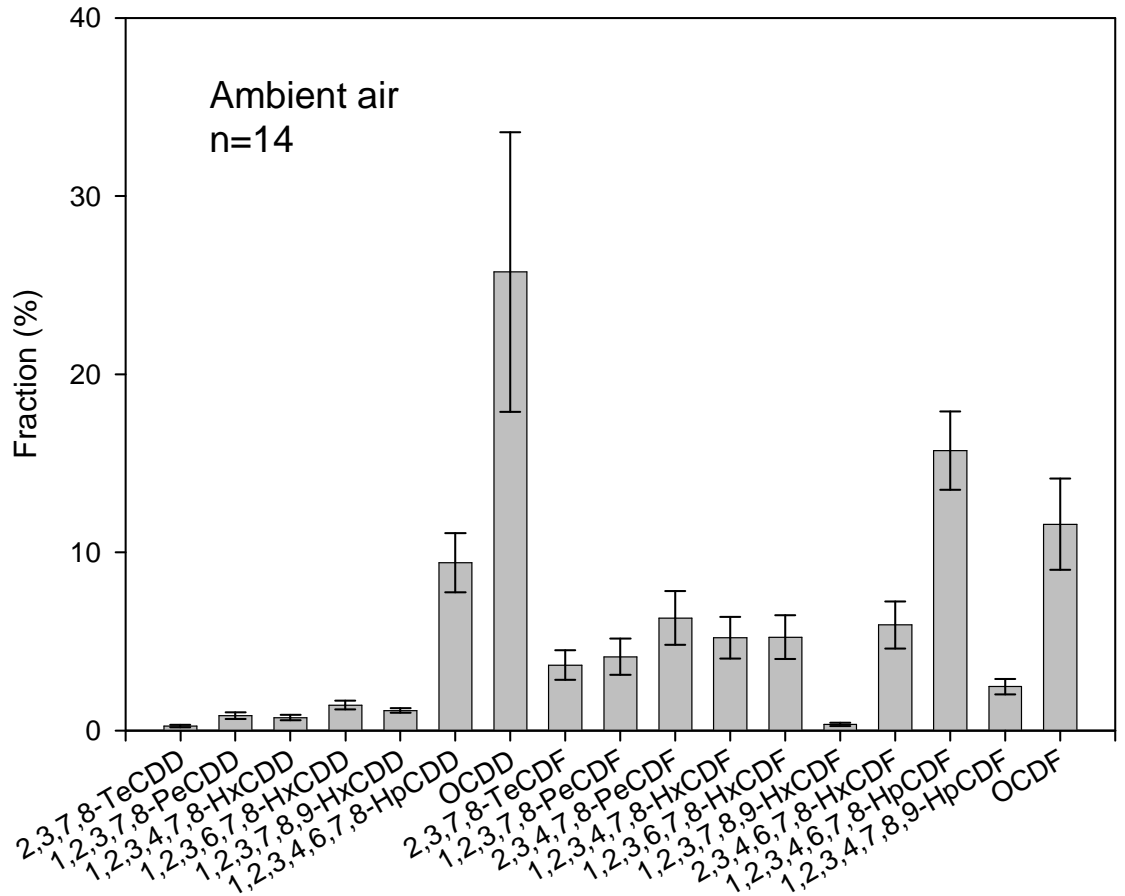

Figure 3. Congener profile of seventeen 2,3,7,8 chlorine-substituted PCDD/Fs in the ambient air of JW.

\section{PCDD/FS IN THE AMBIENT AIR}

The mean PCDD/F concentrations in ambient air ranged between 0.037 and 0.111 and averaged 0.080 pg I-TEQ $\mathrm{Nm}^{-3}$ (RSD: 26.9\%; $\mathrm{n}=14$ ). These concentrations are within the range reported earlier in Hong Kong (Sin et al., 2002), and are very similar to those in residential and traffic areas, but lower than those in the highly industrialized urban area located in southern Taiwan (Lee et al., 2004a; Lee et al. 2004b). They are also are very similar to industrial and urban/rural areas in South Korea (0.07 and 0.08 pg I-TEQ $\mathrm{m}^{-3}$, respectively) (Im et al., 2004). Fig. 3 shows the congener profile of PCDD/Fs of ambient air. It shows that OCDD is the major congener, followed by $1,2,3,4,6,7,8-\mathrm{HpCDF}$, OCDF, and 1,2,3,4,6,7,8-HpCDD, which is consistent with findings in other studies (Coleman et al.,1997; Lee et al., 1999; Sin et al., 2003; Lee et al., 2004a; Lee et al. 2004b).

\section{PCDD/FS IN THE BANYAN LEAF}

The PCDD/F composition in banyan leaves was found to range between 0.804 and 7.48 and

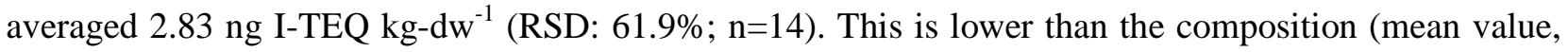
$4.11 \mathrm{ng}$ I-TEQ $\mathrm{kg}_{-}-\mathrm{dw}^{-1}$ ) in grass and weed samples collected in the vicinity of a municipal solid waste 
incinerator in Tarrangona, Catalonia, Spain in 1996 (Schummacher et al., 1997); but it is higher than the

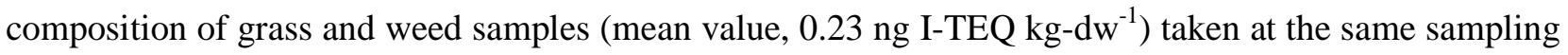
sites in 1997 (Schummacher et al., 1998). This composition is also higher than the herbage samples (mean value of $0.7 \mathrm{ng} \mathrm{I-TEQ} \mathrm{kg}-\mathrm{dw}^{-1}$ ) taken from sites in the vicinity of an old municipal solid waste incinerator in Adrià del Besòs, Barcelona, Spain (Schummacher et al., 2000). Fig. 4 shows the congener profile of PCDD/Fs of the banyan leaves. It shows that OCDD is the major congener, followed by $1,2,3,4,6,7,8-\mathrm{HpCDF}, 1,2,3,4,6,7,8-\mathrm{HpCDD}$, and OCDF, which is similar to that of the ambient air and consistent with findings in other studies (Schummacher et al., 1997; Domingo et al., 2001).

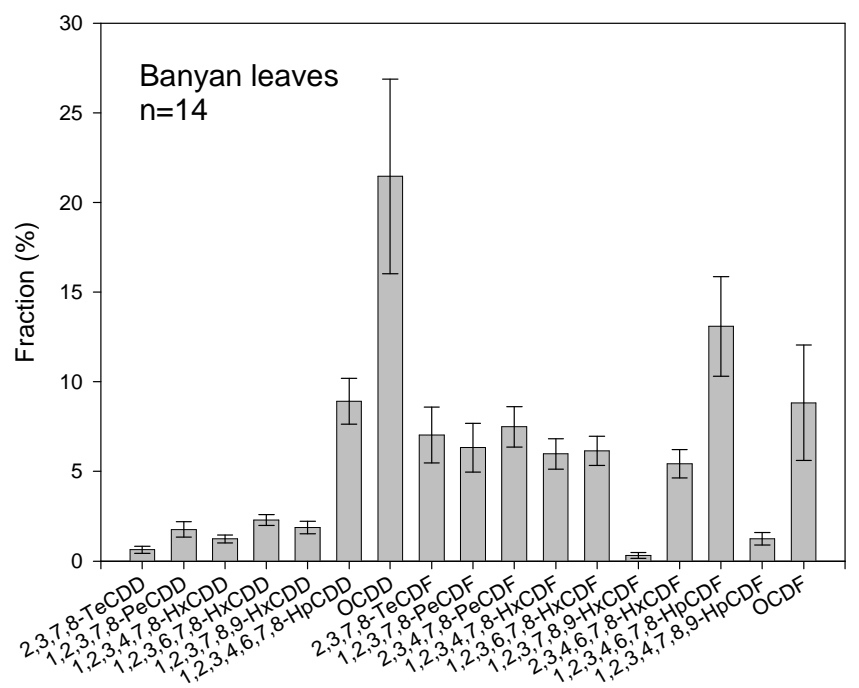

Figure 4. Congener profile of seventeen 2,3,7,8 chlorine-substituted PCDD/Fs in the banyan leaves collected near JW.

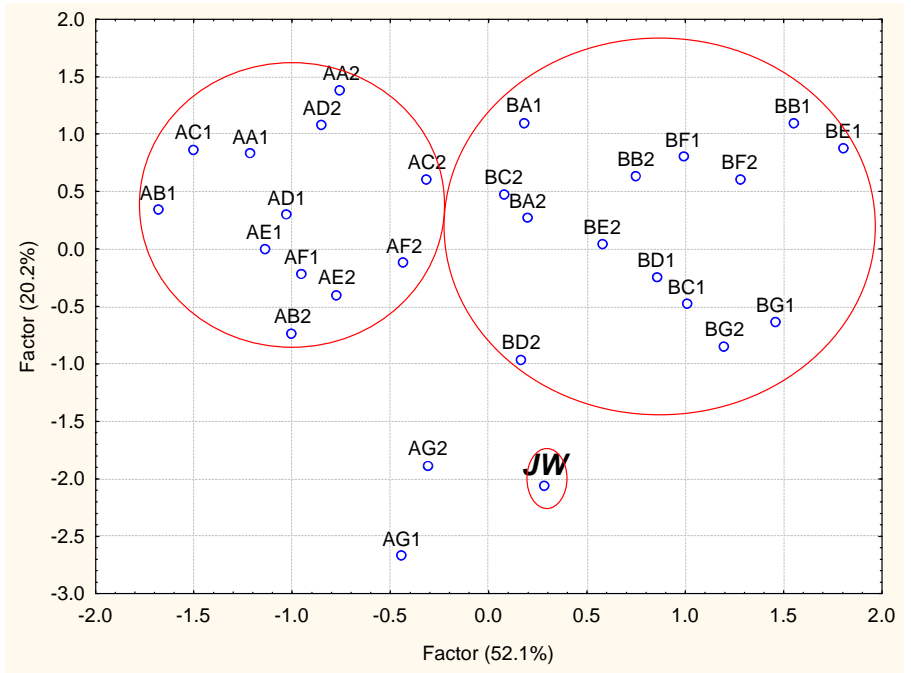

Figure 5. Principal component analysis of 2,3,7,8 chlorine-substituted congener profile (AA: Ambient air of site A, AB: Ambient air of site B, and so on; BA: Banyan leaf of site A, BC: Banyan leaf of site C, and so on). 


\section{RELATIONSHIP BETWEEN EMISSION SOURCE AND RECEPTORS}

Fig. 5 presents the score plot from PCA, in which factor 1 explains $54.1 \%$ of the total variance, while factor 2 explains $27.6 \%$ of the total variance and both account for $81.7 \%$ of the total variance. For each sampling site, the PCDD/F data taken at different periods were averaged.
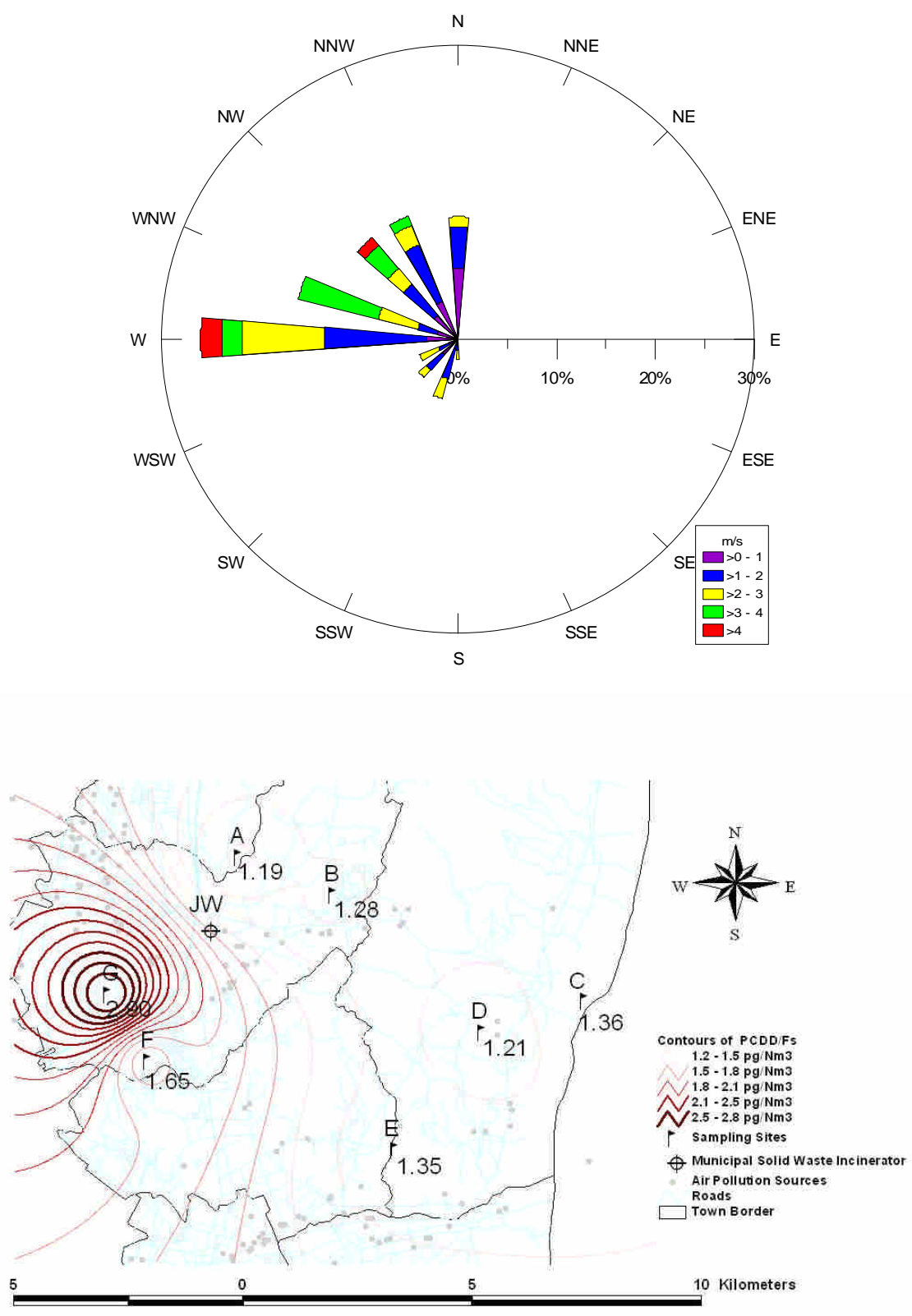

Figure 6. The relationship between ambient air PCDD/F concentration isopleths and wind rose in summer, 2003. 

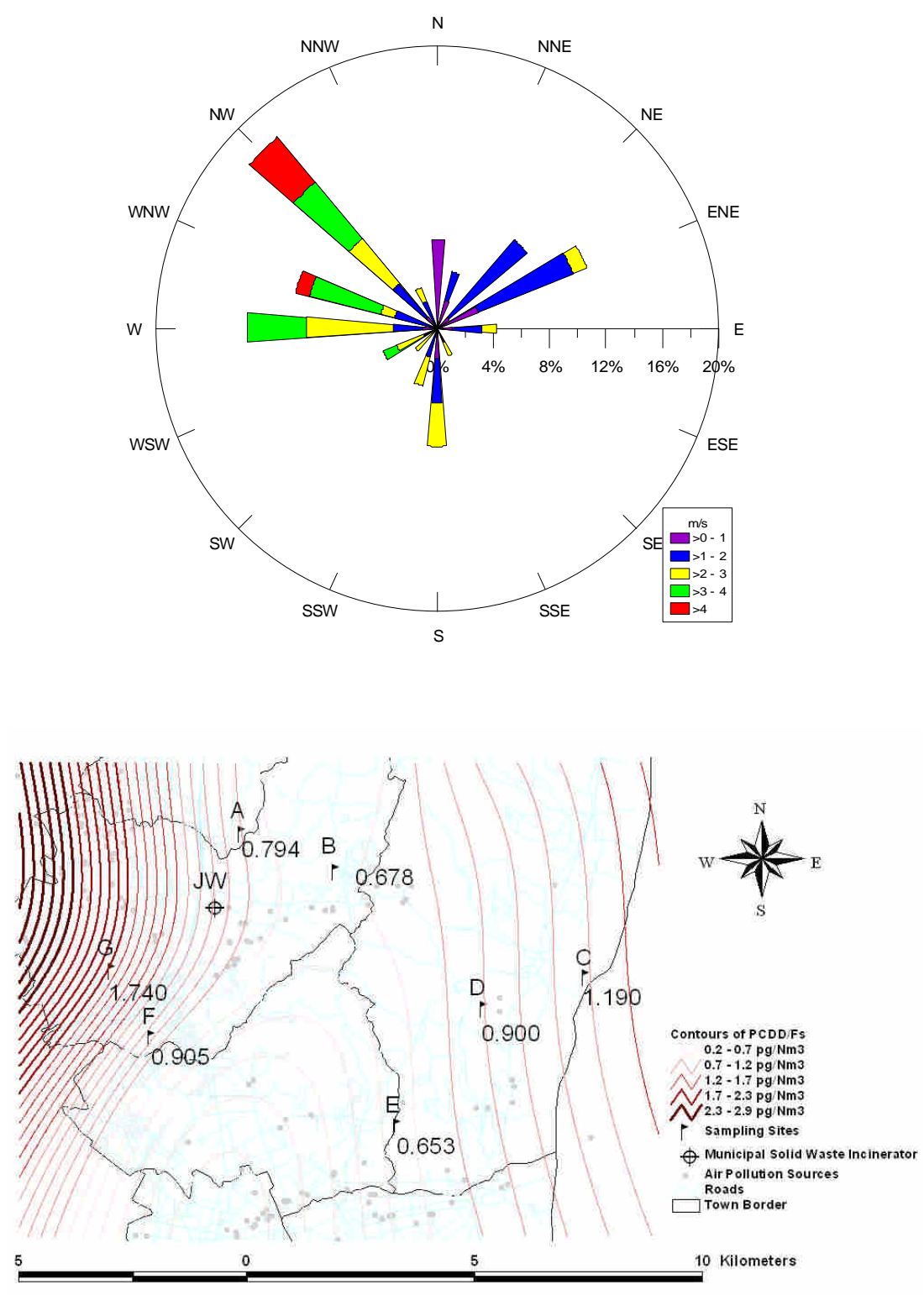

Figure 7. The relationship between ambient air PCDD/F concentration isopleths and wind rose in fall 2003.

The score plot from PCA (Fig. 5) reveals that stack flue gas, ambient air, and banyan leaf samples are divergent to each other; meaning that the correlation between the emission source MSWI-JW and the ambient air receptor is low. It is the same for banyan leaf receptor. Wind rose analysis shows that PCDD/F concentration in ambient air during summer (Fig. 6) and in fall (Fig. 7) sampled upwind was higher than that downwind. In addition, wind rose analysis during 2003 (Fig. 8) showed that the PCDD/F concentration in banyan leaf sampled upwind was higher than that downwind. These figures all reveal the same thing - that the area with high PCDD/F concentration isopleths does not match the geographic 
position of the MSWI-JW and the wind rose. This strongly suggests that the PCDD/F emissions from MSWI-JW have no significant influence on the ambient air and banyan leaf receptors. Also, the results of PCA coincide with the relationship between PCDD/F concentration isopleths and the geographic position of the MSWI-JW and wind rose. These all reveal that the PCDD/F emissions from MSWI-JW have no significant influence on the ambient air and banyan leaf receptors.

Accordingly, the MSWI-JW is not a main contributor of PCDD/Fs in the seven sampling sites of ambient air and seven sampling sites of banyan leaf. Other potential emission sources of PCDD/Fs could be of great concern.
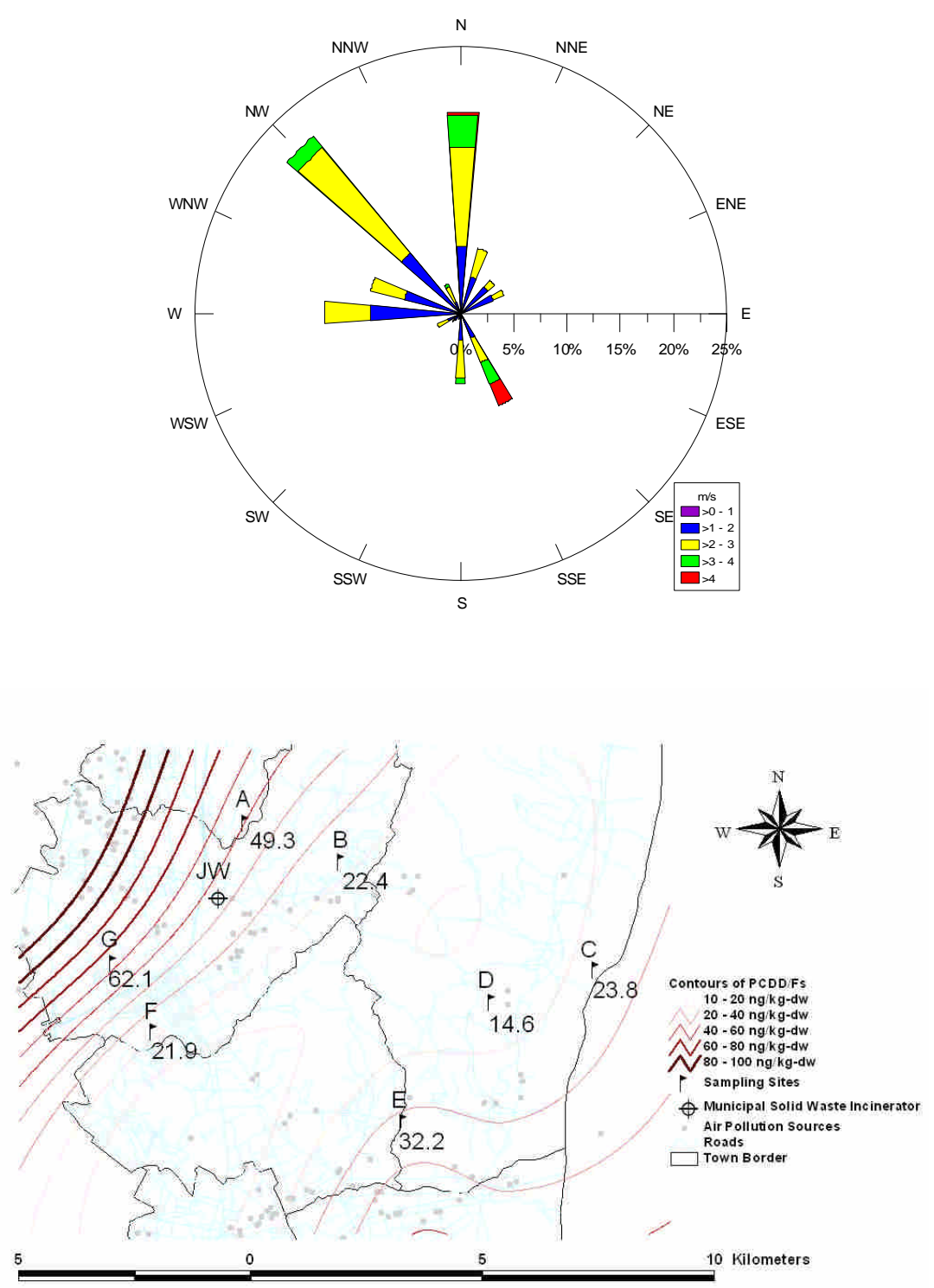

Figure 8. The relationship between banyan leaf PCDD/F concentration isopleths and wind rose in year 2003. 


\section{CONCLUSIONS}

This study found that the observed municipal solid waste incinerator (MSWI-JW) meets Taiwan's $\mathrm{PCDD} / \mathrm{F}$ emission limits, which are the strictest in the world, that the PCDD/F level of ambient air is within the range of industrial and urban/rural areas in South Korea, and that the PCDD/F level of vegetation is higher than those taken from sites in the vicinity of an older municipal solid waste incinerator in Spain. Whether ambient air or banyan leaf, the relationship between PCDD/F concentration isopleths does not match the geographic position of the MSWI-JW and wind rose. In addition, the results of PCA analysis coincide with the relationship between PCDD/F concentration isopleths and the geographic position of the MSWI-JW and wind rose. These all reveal that the PCDD/F emissions from MSWI-JW have no significant influence on the ambient air and banyan leaf receptors. That is to say, the MSWI-JW is not the main contributor of PCDD/Fs in the ambient air and banyan leaf and other potential emission sources of PCDD/Fs could be of greater importance.

\section{References}

Buekens, A., Cornelis, E., Huang, H. and Dewettinck, T., (2000), Fingerprints of Dioxin from Thermal Industrial Processes. Chemosphere 40: 1021-1024.

Coleman, P. J., Lee, R. G. M., Alcock, R. E. and Jones, K. C., (1997), Observations on PAH, PCB, and PCDD/F Trends in U.K. Urban Air 1991-1995. Environ. Sci. Technol. 31: 2120-2124.

Lee, R. G. M., Green, N. J. L., Lohmann, R. and Jones, K. C., (1999), Seasonal, Anthropogenic, Air Mass, and Meteorological Influences on the Atmospheric Concentrations of Polychlorinated Dibenzop-dioxins and Dibenzofurans (PCDD/Fs): Evidence for the Importance of Diffuse Combustion Sources. Environ. Sci. Technol 33: 2864-2871.

Domingo, J. L., Granero, S. and Schuhmacher, M., (2001), Congener Profiles of PCDD/Fs in Soil and Vegetation Samples Collected Near to a Municipal Waste Incinerator. Chemosphere 43: 517-524.

Domingo, J. L., Schuhmacher, M., Agramunt, M. C., Llobet, J. M., Rivera, J. and Müller L., (2002), PCDD/F Levels in the Neighbourhood of a Municipal Solid Waste Incinerator after Introduction of Technical Improvements in the Facility. Environmental International 28: 19-27.

Eduljee, G. H. and Gair, A. J., (1997), Setting Dioxin Emission Limits for MSW Incinerators: A Multimedia Exposure Assessment Framework. Waste Management \& Research 15: 335-348.

Fiedler, H., Kjeller, L. O. and Rappe, C., (1996), Patterns and Sources of Polychlorinated Dibenzo-pdioxins and Dibenzofurans Found in Soil and Sediment Samples in Southern Mississippi. Chemosphere 32: 421-432.

Hung, C.-Y. (2003), Characteristics of Polychlorinated Dibenzo-p-dioxins and Dibenzofurans in the 
Leaves of Ficus Species. Master Thesis, Department of Environmental Engineering, National ChengKung University.

Jambu M., (1991), Exploratory and Multivariate Data Analysis. Academic Press, Boston.

Im, S. H., Strause, K. D., Giesy, J. P., Chang, Y. S., Matsuda, M. and Wakimoto, T., (2004), Concentrations and Accumulation Profiles of Polychlorinated Dibenzo-p-dioxins and Dibenzofurans in Aquatic Tissues, and Ambient Air from South Korea. Chemosphere 55: 1293-1302.

Kim, B. H., Lee, S. J., Mun, S. J. and Chang, Y. S., (2005), A Case Study of Dioxin Monitoring In and Around an Industrial Waste Incinerator in Korea. Chemosphere 58: 1589-1599.

Lee, W. S., Chang-Chien, G. P., Wang, L. C., Lee, W. J., Tsai, P. J., Wu, K.Y. and Lin C., (2004a), Source Identification of PCDD/Fs for Various Atmospheric Environments in a Highly Industrialized City. Environ. Sci. Technol. 38: 4937-4944.

Lee, W. S., Yuan, C. S., Wang, L. C., Chen, C. K., Lin, C. and Chang-Chien, G. P., (2004b), Evaluating the Influence of PCDD/F Emission from Municipal Solid Waste Incinerators on Ambient Air by PCDD/F Concentration Isopleths and Principal Component Analysis. Journal of the Chinese Institute of Environmental Engineering 14:1-10.

Lee, W. S., Chang-Chien, G. P., Wang, L. C., Lee, W. J., Tsai, P. J. and Chen, C. K., (2003), Emissions of Polychlorinated Dibenzo-p-dioxins and Dibenzofurans from the Incinerators of both Medical and Municipal Solid Wastes. Aerosol and Air Quality Research 3: 1-6.

Mukerjee, D., (1998), Health Impact of Polychlorinated Dibenzo-p-dioxins: A Critical Review. Occupational Health and Industrial Medicine 38: 235-236.

Nadal, M., Agramunt, M. C., Schuhmacher, M. and Domingo, J. L., (2002), Congener Profiles in Soil and Herbage Samples Collected in the Vicinity of a Municipal Solid Waste Incinerator Before and After Pronounced Reductions of PCDD/PCDF Emissions from the Facility. Chemosphere 49: 153-159. Schuhmacher, M., Domingo, J. L., Llobet, J. M., Müller L. and Jager, J. (1997), Levels of PCDDs and PCDFs in Grasses and Weeds Collected near a Municipal Solid Waste Incinerator. Sci. Total Environ. 201: 53-62.

Schuhmacher, M., Domingo, J. L., Llobet, J. M., Sünder hauf, W. and Müller L., (1998), Temporal Variation of PCDD/F Concentrations in Vegetation Samples Collected in the Vicinity of a Municipal Waste Incinerator (1996-1997). Sci. Total Environ. 218: 175-183.

Schuhmacher, M., Granero, S., Rivera, J., Müller L., Müller L., Llobet, J. M. and Domingo, J. L., (2000), Atmospheric Deposition of PCDD/Fs Near an Old Municipal Solid Waste Incinerator: Levels in Soil and Vegetation. Chemosphere 40: 593-600.

Schuhmacher, M., Bocio, A., Agramunt, M. C., Domingo, J. L. and de Kok, H. A. M., (2002), PCDD/F and Metal Concentrations in Soil and Herbage Samples Collected in the Vicinity of a Cement Plant. Chemosphere 48: 209-217. 
Sin, D. W.-M., Choi, J. Y.-Y. and Louie, K.-K., (2002), A Study of Polychlorinated Dibenzo-p-dioxins and Dibenzofurans in the Atmosphere of Hong Kong. Chemosphere 47: 647-653.

USEPA, (1995), EPA’s Dioxin Reassessment. Environ. Sci. Technol 29: 26A-28A

USEPA, (1998), The Inventory of Sources of Dioxin in the United States, EPA/600/P-98/002Aa, 3-1-384 .

Wang, L. C., Lee, W. J., Lee, W. S., Chang-Chien, G. P. and Tsai, P. J. (2003A), Characterizing the Emission of Polychlorinated Dibenzo-p-dioxins and Dibenzofurans from Crematories and Their Impacts to the Surrounding Environment. Environ. Sci. Technol. 37: 62-67.

Wang, L. C., Lee, W. J., Tsai, P. J., Lee, W. S. and Chang-Chien, G. P., (2003B), Emissions of Polychlorinated Dibenzo- $p$-dioxins and Dibenzofurans from Stack Flue Gases of Sinter Plants. Chemosphere 50: 1123-1129.

Received for review, June 7, 2005 Accepted, October 6, 2005 